Cousins, E. R. Guice, W. A. \& Feuge, R. O. (1959). F. Amer. Oil Chem. Soc. 36, 24.

Deuel, H. J. Jr., Greenberg, S. M., Anisfeld, L. \& Melnick, D. (1951). F. Nutr. 45, 535.

Emmet, P. H. (1959). F. phys. Chem. 63, 449.

Feuge, R. O. \& Cousins, E. R. (I 960). F. Amer. Oil Chem. Soc. 37, 267.

Feuge, R. O., Cousins, E. R., Fore, S. P., DuPre, E. F. \& O'Conner, R. T. (1953). f. Amer. Oil Chem. Soc. 30, 454 .

Feuge, R. O., Pepper, M. B. Jr., O’Conner, R. T. \& Field, E. T. (I951). Y. Amer. Oil Chem. Soc. 28, 420 .

Funch, J. P., Aaes-Jørgensen, E. \& Dam, H. (1957). Brit. Y. Nutr. r1, 426 .

Funch, J. P., Jart, A. \& Dam, H. (1960). Brit. F. Nutr. I4, I7I.

Hartman, L., Shorland, F. B. \& Cleverley, B. (1958). Biochem. F. 69, r.

Hilditch, T. P. \& Vidyarthi, N. L. (1929). Proc. roy. Soc. A, 122, 552.

Holman, R. T. (1951). Proc. Soc. exp. Biol., N.Y., 76, 100

Holman, R. T. \& Aaes-Jorgensen, E. (1956). Proc. Soc. exp. Biol., N.Y., 93, 175.

Holman, R. T. \& Greenberg, S. I. (1954). Arch. Biochem. Biophys. 49, 49.

Johnston, P. V., Johnson, O. C. \& Kummerow, F. A. (1957). Proc. Soc. exp. Biol., N.Y., 96, 760.

Johnston, P. V., Johnson, O. C. \& Kummerow, F. A. (1958). F. Nutr. 65, I3.

Johnston, P. V., Kummerow, F. A. \& Walton, C. H. (1958). Proc. Soc. exp. Biol., N.Y., 99, 735.

Kaufmann, H. P. \& Dransfeld, H. (1960). Fette, Seif. u. Anstrichmit. 62, 73.

Klenk, E. (1958). In Essential Fatty Acids, p. 57. [H. M. Sinclair, editor.] London: Butterworths Scientific Publications.

Klenk, E. \& Debuch, H. (1959). Annu. Rev. Biochem. 28, 39.

Mabrouk, A. F. \& Brown, J. B. (1956). F. Amer. Oil Chem. Soc. 33, 98.

Mattson, F. H. (1960). F. Nutr. 71, 366 .

Moore, C. W. (1919). F. Soc. chem. Ind., Lond., 38, 320T.

Miller, E. S. \& Burr, G. O. (1937). Proc. Soc. exp. Biol., N. Y., 36, 726.

Peifer, J. J. \& Holman, R. T. (1959). F. Nutr. 68, I55.

Privett, O. S., Aaes-Jørgensen, E., Holman, R. T. \& Lundberg, W. O. (r959). F. Nutr. 67, 423.

Privett, O. S., Lundberg, W. O., Khan, N. A., Tolberg, W. \& Wheeler, D. J. (1953). F. Amer. Oil Chem. Soc. 30, 61.

Privett, O. S., Pusch, F. J. \& Holman, R. T. (I955). Arch. Biochem. Biophys. 57, I 56.

Privett, O. S., Pusch, F. J., Holman, R. T. \& Lundberg, W. O. (1960). F. Nutr. 71, 66.

Reiser, R. (195I). Arch. Biochem. Biophys. 32, I 3 .

Scholfield, C. R., Jones, E. P., Nowakowska, J., Selke, E., Sreenivasan, B. \& Dutton, H. J. (1960). F. Amer. Oil Chem. Soc. 37, 579 .

Thomasson, H. J. (1953a). Int. Z. Vitaminforsch. 25, 62.

Thomasson, H. J. (1953b). In International Conference on Biochemical Problems of Lipids, p. 212. [R. Ruyssen, editor.] Brussels: Palais der Academiën.

Thomasson, H. J. (1955). F. Nutr. 56, 455 .

Thomasson, H. J. (1956a). F. Nutr. 59, 343 .

Thomasson, H. J. (1956b), In International Conference on Biochemical Problems of Lipids, p. 452. [G. Popják and E. LeBreton, editors.] London: Butterworths Scientific Publications.

Thomasson, H. J. \& Gottenbos, J. J. (1957). Verh. vlaam. Akad. Geneesk. Belg. 19, 369.

\title{
Fats and atherosclerosis in fowls
}

\section{By W. G. Siller and W. Bolton, Agricultural Research Council Poultry Research Centre, West Mains Road, Edinburgh 9}

The finding that atheromatous plaques contained lipid, and especially cholesterol, prompted research on the production of this disease by addition of this sterol to the diet. Several species of experimental animals have been used; the fowl, being omnivorous and susceptible to spontaneous atherosclerosis, has proved popular for research (Katz \& Stamler, I953).

Kinsell, Partridge, Boling, Margen \& Michaels (1952) and many later workers (cf. van Itallie, 1957) observed that the addition to human diets of vegetable fats, 
but not of those of animal origin, lowered both the serum cholesterol and phospholipid levels. Later, however, this distinction was attributed not to the origin of the fats but to differences in their fatty-acid composition. The serum cholesterol level was raised by fats in which saturated acids predominated and lowered by those high in unsaturated acids (cf. Bronte-Stewart, 1960).

In view of the possible association between atherosclerosis and hypercholesterolaemia, the discovery of agents that depressed the plasma cholesterol level immediately precipitated an avalanche of research on the effect of unsaturated fatty acids on blood cholesterol level in various species.

The results of all this work are somewhat contradictory and, with respect to the fowl, are confused at the present stage.

\section{Unsaturated fat as supplements}

When given to adult hens for 20 months, unsaturated fats (maize oil) added to a normal diet (unsupplemented with cholesterol) are reported by Gey \& Pletscher (1 $9^{61}$ ) to affect neither the serum cholesterol level nor the severity of aortic lesions. Likewise, Dam, Kristensen, Nielsen \& Søndergaard (1959) obtained no change in cholesterol content of plasma or aorta in fowls whose diet was supplemented only by unsaturated fat (linseed oil). In adult cockerels on a diet supplemented by maize oil $(0.1-I 5 \%)$ for $12-18$ months Kokatnur, Rand, Kummerow \& Scott (I958) produced a rise in serum cholesterol level which was most marked if the dietary protein was low; they did not report on the atherosclerotic lesions. Fisher, Feigenbaum, Leveille, Weiss \& Griminger (1959) showed that a diet containing $10 \%$ linseed oil raised the serum cholesterol level by $16 \%$ in 20 -month-old hens when given for the subsequent year; there was a decrease in the severity of the lesions, particularly in the abdominal aorta, compared with those in birds not receiving oil. After such a diet had been given to female birds from the 8th to the 20 th month of age, the serum cholesterol levels were normal and no change was noted in the aortic score, but there was a marked drop in the total amount of fat in the aorta (by $40 \%$ in the thoracic and $33 \%$ in the abdominal segments). Particularly in the latter there was a considerable rise in the oleic-acid content and a drop in that of both saturated and polyenoic acids. Fisher, Weiss, Leveille, Feigenbaum, Hurwitz, Donis \& Lutz ( 1960 ) report an insignificant rise of about $10 \%$ in the serum cholesterol level in birds fed for 3 years on a diet supplemented with $10 \%$ maize oil. Though there was a $16 \%$ increase in the aortic cholesterol content of these fowls the score for aortic lesions was lower by $28 \%$ than that of the controls.

\section{Cholesterol supplements with fats}

In cholesterol-fed birds the consensus of opinion is that unsaturated fats reduce the hypercholesterolaemia (Tennent, Zanetti, Siegel, Kuron \& Ott, 1959; Hegsted, Gotsis \& Stare, I960). Kokatnur et al. (1958) point out that this effect is most pronounced when maize oil is added to a diet containing $30 \%$ protein. Fisher et al. (1959) have shown that in order to obtain the same degree of hypercholesterolaemia 
in fowls on diets without supplemental fat a much higher cholesterol intake is required with a high- than with a low-protein diet. These workers (Leveille \& Fisher, 1958) had already shown that the plasma cholesterol levels in birds on diets containing $25 \%$ protein, $2 \%$ cholesterol and various fats was essentially normal. They suggest that if the fowl has an adequate protein intake it can metabolize the excessive dietary cholesterol.

On the other hand, Stamler, Pick \& Katz (1959) report that the addition to the diet of $10 \%$ unsaturated fats had no depressing effect on the hypercholesterolaemia, although they do credit oleic acid in high concentrations with such an effect. Dam et al. (1959) claim an increase of $175 \%$ in serum cholesterol level in fowls fed on $10 \%$ linseed oil, and a 55\% increase in the aortic cholesterol level when the diet was supplemented with both cholesterol and unsaturated fats; however, they used only five birds per group and the within-group variance was large. Stamler et al. (1959) found that unsaturated fats had no effect on aortic lesions, and Tennent et al. (1959) claim that, in fowls, there is no relationship between the severity of the atherosclerotic lesions and dietary fat.

There is some doubt, therefore, even with cholesterol-fed fowls, about the effect of adding unsaturated fats to the diet.

\section{Saturated fats as supplements}

The majority of workers are in agreement about the effect of saturated fats on hypercholesterolaemia in fowls given cholesterol in the diet. Tennent et al. (1959) and Hegsted et al. (1960) reported a rise in the serum cholesterol level. In fowls given saturated fats without cholesterol Fisher et al. (1960) found a moderate rise in the serum cholesterol level and a $50 \%$ increase in the aortic cholesterol content (as a percentage of dry defatted tissue) with a marked $(20 \%)$ decrease in the severity of the lesions.

Stamler et al. (1959) reported that the severity of the atherosclerosis and the serum cholesterol level were unchanged in fowls given $10 \%$ saturated fats and $\mathrm{r} \%$ cholesterol in the diet.

Because the experimental procedures were so varied it is difficult to assess the implications of these different experiments. Different fats were often used and even fats of the same name can have very different fatty-acid compositions, depending on their origin. Thus a certain type of linseed oil from New Zealand had an oleic-acid content of $9 \%$ compared with $29 \%$ in an Argentine sample; the contents of saturated fatty acid in the two samples were 13.4 and $6 \%$ respectively (Hilditch, 1956). That the sex and age of the fowls used may be of great importance is shown by the excellent work of Fisher et al. (1959) who recorded no change in the serum cholesterol level of pullets fed from 8 to 20 months of age on a diet supplemented with either $10 \%$ linseed oil or $10 \%$ tallow, whereas hens from 20 to 32 months old given similar diets showed a rise in serum cholesterol of $16 \%$ and $31 \%$ respectively. In these two age groups there was also a marked difference in the aortic score, the total aortic fat content and the distribution of aortic fatty acids (see Table r). 
Table I. Changes in aortic score for degree of atherosclerosis, total aortic fat content (as percentage of dry defatted tissue) and content of fatty acids (as percentage of total fat) in pullets and hens on a diet supplemented with $10 \%$ linseed oil in relation to controls not given the supplement

(From the data of Fisher et al. 1959)

$\begin{array}{ccc} & \text { Pullets } & \text { Hens } \\ \text { Aortic score: } & \text { No change } & 8 \% \text { drop } \\ \text { Thoracic } & 8 \% \text { rise } & 20 \% \text { drop } \\ \text { Abdominal } & & \\ \text { Total aortic fat: } & 40 \% \text { drop } & 7 \% \text { drop } \\ \text { Thoracic } & 33 \% \text { drop } & 5 \% \text { rise } \\ \text { Abdominal } & 11 \% \text { rise in content of } & \begin{array}{c}\text { Drop in content of oleic } \\ \text { acid, rise in that of }\end{array} \\ \text { Fatty-acid composition } & \text { oleic acid } & \text { linoleic acid } \\ \text { of the abdominal aorta } & & \end{array}$

If it is accepted that unsaturated fats affect both the serum cholesterol level and the atherosclerotic lesions, which appears from the foregoing to be doubtful in the fowl at any rate, it is still not known whether the important factor is the high overall content of double bonds, the increased content of polyunsaturated fats, essential fatty acids or plant steroids, or merely a lowered intake of saturated fats.

Stamler et al. (1959) dismiss this question by implying that in fowls the level of dietary cholesterol is the important factor. They argue that in man the 'experimental regimens entailed substitution, partial or complete, of unsaturated oils for saturated fats, with an associated reduction in cholesterol intake'. This argument is countered by the early observations of Kinsell et al. (1952) who found that the serum cholesterol level, depressed by the intake of vegetable fats, could not be raised by the daily intake of as much as $60 \mathrm{~g}$ cholesterol.

Fisher, Weiss \& Griminger (196r) present some evidence to show that maize steroids play an important part. This contention is supported by Peterson, Nichols \& Shneour (1952), who found that soya-bean steroids prevented hypercholesterolaemia in cholesterol-fed fowls and also depressed the incidence of atherosclerosis.

Tennent et al. (1959) believe the plasma cholesterol level to be inversely proportional to the content of polyenoic acid in the diet. Jones, Reiss \& Huffman (1956) concluded that the effect of unsaturated fats on the serum cholesterol level cannot be accounted for solely by their fatty-acid composition. Hegsted, Gotsis \& Stare (1957) reported that the sum of the total saturated fatty acids and the essential fatty acids of the dietary fat was inversely proportional to the serum cholesterol content in rats. It was not so in fowls (Leveille \& Fisher, 1958). Hegsted et al. (1960) suggested that the iodine value of the fat may be the most significant factor and that maize and cottonseed oils may contain non-fatty acid substances which lower the serum cholesterol level. Wilkens (1959) suggested that since cholesterol is more soluble in saturated than in unsaturated fats the response of the serum cholesterol level to endogenous sterol may be dependent on the nature of the fat present.

The change in the content of cholesterol esters of the aortic tissue in fowls given unsaturated fats is of interest. Blomstrand \& Christensen (196r) have shown a $24 \%$ 
increase in the presence of unsaturated cholesteryl esters when $\mathrm{I} \%$ of the sterol was included in the diet. This increase became more marked (55\%) after the simultaneous inclusion of $\mathrm{I} \%$ cholesterol and $3 \%$ arachis oil in the diet. In the latter group the oleic-acid content of the aorta rose by $54 \%$ at the expense of, mainly, the saturated esters (cf. the observations of Fisher et al. (1959, Table I)). In man, Böttcher, Woodford, Ter Haar Romeny-Wachter, Boelsma-Van Houte \& Van Gent (I960) found that with advancing atherosclerosis there was a progressive increase in the proportion of polyunsaturated cholesteryl esters from 29 to $46 \%$ in the aorta and a decrease from $3^{\mathrm{r}}$ to $17 \%$ in saturated acids, whereas the monoenoic fatty acids showed no significant change. Such discrepancies are a warning against too free drawing of species-to-species analogies!

The changes in the contents of elastin, collagen and total hexosamines of the spontaneously atheromatous aorta of fowls were studied by Buddecke (1958) and found to be similar to those in man.

Labella (r957) has postulated that elastin is a metabolically active lipoprotein, in which the lipid moiety is derived largely from unsaturated fatty acid, but Loomeijer ( $196 \mathrm{r}$ ) does not confirm this view. Since elastin tissue shows early involvement and degeneration in atherosclerosis, Labella suggested that elastin breakdown may be initiated by the replacement of unsaturated by saturated fatty acids. The increased accumulation of unsaturated acids in the diseased aorta supports this hypothesis, since the unsaturated fatty acids would be unextractable while bound in the intact elastin molecule, but liberated on degradation. This idea is not antagonistic to the theory of Sinclair (1956) that a deficiency of essential fatty acids is the primary cause of atherosclerosis. It may also be mentioned that Swell, Field \& Treadwell ( 1960 ) reported a positive correlation between the arachidonic-acid level of normal serum and resistance to atherosclerosis in different species.

Great stress has been laid on the effects of unsaturated fats on the serum cholesterol level, yet there is considerable doubt whether the degree of hypercholesterolaemia is an index of the severity of atherosclerosis or that the severity of the lesion is paralleled by the lipid content in the aorta. Different species vary in their response to dietary cholesterol in respect of serum levels and lipid deposition in the vessels (Rannie, 1956). In the fowl, Feigenbaum, Fisher, Leveille, Weiss \& Griminger (196I) have shown that there is a lack of relationship between plasma or aortic cholesterol concentrations on the one hand and the degree of atherosclerotic involvement on the other. But according to Fisher \& Feigenbaum (1960) 'there is an inverse relationship between the severity of the atherosclerotic involvement (visual score) and the level of essential fatty acids in the plaque tissue'.

The significant criterion in the assessment of the beneficial effects of any agent, would therefore appear to be its effect on the atherosclerotic lesion itself and not on the lipid concentrations in plasma or vessel wall.

Criticism has been levelled against the repeated and sometimes undoubtedly too dogmatic drawing of analogies between experimental atherosclerosis and the spontaneous disease of man. A number of striking differences have been briefly 
mentioned elsewhere (Siller, I96I). The aortic lesions in fowls, produced by exogenous cholesterol or oestrogen are usually reported to be most severe in the thoracic segment (Katz \& Stamler, 1953). This is unlike spontaneous atherosclerosis in either man or the fowl. On the other hand, Fisher and his collaborators have repeatedly found that the experimental aortic lesions were more severe in the abdominal segment (cf. Fisher et al. 1960). In an experiment reported by Siller (196I), fowls fed from hatching exclusively on eggs showed an abdominal distribution of aortic lesions similar to the spontaneous disease in man and in the fowl. It is unfortunate that the pathological material came from an experiment not primarily designed to study atherosclerosis, and that neither the customary biochemical information on serum or aortic lipids nor exact analyses of the fats in the diet are available.

It was found, however, that of the birds on this egg diet which survived 5 weeks $75 \%$ had atherosclerotic lesions. It is interesting to note that four of these birds died from rupture of the thoracic aorta (Siller, 196r, to be published), although the atherosclerotic lesions tended to be predominantly abdominal. It is hardly surprising that a diet consisting of about 50\% protein and 50\% lipids (dry-weight basis) should produce lesions in the fowl which differ in some respects from those arising spontaneously in man; for example the intrasplenic arteries in these fowls showed severe medial involvement. Although, as has already been stated, the diet was not analysed it can be calculated from the data of Bolton (196r) and Hilditch (1956) that, on a dry-weight basis, its approximate total content of fatty acids was about $38 \%$ (14\% saturated, $18 \%$ monoenoic and $6 \%$ polyenoic). It must be remembered, however, that the fatty-acid composition of eggs depends on the diet of the hens (Cruickshank, 1934; Choudhury \& Reisner, 1959).

\section{REFERENCES}

Blomstrand, R. \& Christensen, S. (1961). Nature, Lond., 189, 376.

Bolton, W. (I96r). In Biochemists' Handbook, p. 763. [C. Long, editor.] London: E. and F. N. Spon. Böttcher, C. J. F., Woodford, F. P., Ter Haar Romeny-Wachter, C. C., Boelsma-Van Houte, E. \& Van Gent, C. M. (1960). Lancet, i, 1378 .

Bronte-Stewart, B. (1960). Proc. int. Congr. Nutr. v. Washington, 3, 12.

Buddecke, E. (1958). Z. physiol. Chem. 310, 199.

Choudhury, B. R. \& Reisner, R. (I959). F. Nutr. 68, 457.

Cruickshank, E. M. (1 934). Biochem. F. 28, 965.

Dam, H., Kristensen, G., Nielsen, G. K. \& Søndergaard, E. (1959). Acta physiol. scand. 45, 31.

Feigenbaum, A. S., Fisher, H., Leveille, G. A., Weiss, H. S. \& Griminger, P. (r96r). f. Amer. Oil Chem. Soc. 38, 93 .

Fisher, H., Feigenbaum, A., Leveille, G. A., Weiss, H. S. \& Griminger, P. (1959). J. Nutr. 69, I63.

Fisher, H. \& Feigenbaum, A. S. (1960). Nature, Lond., 186, 87.

Fisher, H., Weiss, H. S. \& Griminger, P. (196r). Proc. Soc. exp. Biol., N.Y., ro6, 61.

Fisher, H., Weiss, H. S., Leveille, G. A., Feigenbaum, A. S., Hurwitz, S., Donis, O. \& Lutz, H. (1960). Brit. F. Nutr. I4, 433.

Gey, K. F. \& Pletscher, A. (1961). Nature, Lond., 189, 49 I.

Hegsted, D. M., Gotsis, A. \& Stare, F. J. (1957). F. Nutr. 63, 377.

Hegsted, D. M., Gotsis, A. \& Stare, F. J. (1960). F. Nutr. 70, 119.

Hilditch, T. P. (1956). The Chemical Constitution of Natural Fats, 3 rd ed. London: Chapman \& Hall. Jones, R. J., Reiss, O. K. \& Huffman, S. (1956). Proc. Soc. exp. Biol., N.Y., 93, 88.

Katz, L. N. \& Stamler, J. (1953). Experimental Atherosclerosis. Springfield, Ill.: Charles C. Thomas.

Kinsell, L. W., Partridge, J., Boling, L., Margen, S. \& Michaels, G. (1952). F. clin. Endocrin. 12, 909. Kokatnur, M., Rand, N. T., Kummerow, F. A. \& Scott, H. M. (1958). F. Nutr. 64, 177. 
Labella, F. S. (1957). Nature, Lond., 180, I36o.

Leveille, G. A. \& Fisher, H. (1958). Proc. Soc. exp. Biol., N.Y., 98, 630.

Loomeijer, F. J. (1961). F. Atheroscler. Res. 1, 62.

Peterson, D. W., Nichols, C. W. \& Shneour, E. A. (1952). F. Nutr. 47, 57.

Rannie, I. (1956). Proc. Nutr. Soc. 15, 61.

Siller, W. G. (1961). 7. Atheroscler. Res. (In the Press.)

Sinclair, H. M. (1956). Lancet, i, 38 r.

Stamler, J., Pick, R. \& Katz, L. N. (I959). Circulation Res. 7, 398.

Swell, L., Field, H. \& Treadwell, C. R. (I960). Proc. Soc. exp. Biol., N.Y., 104, 325.

Tennent, D. M., Zanetti, M. E., Siegel, H., Kuron, G. W. \& Ott, W. H. (1959). अ. Nutr. 69, 283.

van Itallie, T. B. (1957). Nutr. Rev. I5, x.

Wilkens, J. A. (1959). S. Afr. med. F. 33, 1076.

\section{Lipids and atherosclerosis in man}

\section{By M. F. Oliver, Department of Cardiology, Royal Infirmary, Edinburgh}

Probably the main contribution which a physician can make to this symposium is an assessment of the aetiological and therapeutic importance of animal and vegetable fats in terms of human disease. Although it has been speculated that a deficiency of essential fatty acids might contribute to various diseases in man, atherosclerosis is the disease in which animal and vegetable fats have been most closely implicated and is the only disease which will be considered here. The object of this discussion is to examine briefly the nature of certain associations and the strength of certain relationships which may exist between dietary fat and human atherosclerosis rather than to review them in any detail; several comprehensive reviews have been published recently (Hilditch \& Jasperson, 1959; Katz, Stamler \& Pick, I959; Oliver, г960 $b$; Sinclair, r960).

\section{Arterial lipids and atherosclerosis}

The earliest visible lesions in human arteries are fatty streaks on the intimal surface. There is little or no associated fibrosis in these early lesions which are present in many by the age of 5 years and in the majority of ro-year-olds in this country. The fat in these lesions is mostly esterified and free cholesterol, and these lipids increase greatly with the severity of atherosclerosis mainly at the expense of the phospholipids and triglycerides; this is so for the coronary and cerebral arteries and is particularly striking in the aorta. Although there are differences between these arteries, with increasing atherosclerosis the polyunsaturated fatty acids of cholesterol esters also increase while those of phospholipids decrease (Böttcher, Boelsma-Van Houte, Ter Haar Romeny-Wachter, Woodford \& Van Gent, I960).

Cholesterol can be synthesized in the arterial wall, but this property decreases with advancing age and most of the esterified and free cholesterol is derived from the plasma. In addition to the evidence from experimentally induced atherosclerosis that the level and duration of plasma hypercholesterolaemia is roughly responsible for the extent and degree of atheromatous-like lesions, there is adequate evidence from studies with isotopes in man that cholesterol in the plasma passes across the 